\title{
Experimental Studies on the Pneumoconiosis Caused by Inhalation of Titan Dust
}

\author{
Mitsuru SHIRAKAWA \\ Department of Hygiene, Miyazaki Medical College, \\ Kiyotake-cho, Miyazaki 889-16, Japan
}

(Received October 11, 1984 and in revised form March 4, 1985)

\begin{abstract}
Titan dust containing about $50 \% \mathrm{Ti}$, and titanium hydride $\left(\mathrm{TiH}_{2}\right)$ containing $99.97 \% \mathrm{Ti}$ were inhaled by rats and rabbits. $\mathrm{TiH}_{2}$ dust was infused intratracheally in rats, and the effects of titan dust on the laboratory animals were tested. Rats and rabbits were exposed to titan dust at concentrations of 22.4, 70.5, and $476 \mathrm{mg} / \mathrm{m}^{3}$ for periods ranging from 1 month to about one year, and those surviving were observed for about one year. In the case of $\mathrm{TiH}_{2}$ dust, rats and rabbits were exposed to a concentration of around $529 \mathrm{mg} / \mathrm{m}^{3}$ for priods of 2 to 8 months, the $\mathrm{TiH}_{2}$ dust being infused intratracheally in the case of rats. Radiologically in rabbits, obvious nodular shadows were revealed in the chests of rabbits exposed to titan dust, and such findings increased chronologically. Histopathologically, retention of the fine dust in alveoli and lymph nodes, proliferation of the alveolar walls, hyperplasia of connective tissue cells, and phagocytes and macrophages containing absorbed dust particles were found together with fibrosis. Suspensions of the $\mathrm{TiH}_{2}$ dust in physiological saline solution containing 10, 50, 100, and $500 \mathrm{mg}$ in $1 \mathrm{ml}$ respectively, were infused intratracheally in 39 male rats. In this intratracheal infusion group and the $\mathrm{TiH}_{2}$ inhalation group changes in bronchioli, lung and lymph nodes, dust cells and giant cells, bronchopneumonia and granulomatous pneumonia, and intraalveolar fibrosis were shown. As a result of these investigation, it was concluded that the inhalation of titan dust or titan compounds such as $\mathrm{TiH}_{2}$ can produce respiratory disorders and pulmonary fibrosis (titanosis) in laboratory animals.
\end{abstract}

Key words: Pneumoconiosis-Titan-Titan dust-Titanium hydride-Titanosis

\section{INTRODUCTION}

According to a radiological examination of 19 titan workers ranging in age from 19 to 52 years who were engaged in titan tipping work and exposed to titan dust for several years at the Osaka Titanium Manufacturing Co., Ltd. in Hyogo Prefecture, $15(79.0 \%)$ of the workers showed reticulonodular shadowing on their chest roentgenograms in August, 1963.

Therefore, using laboratory animals for experimental studies on the pneumo- 


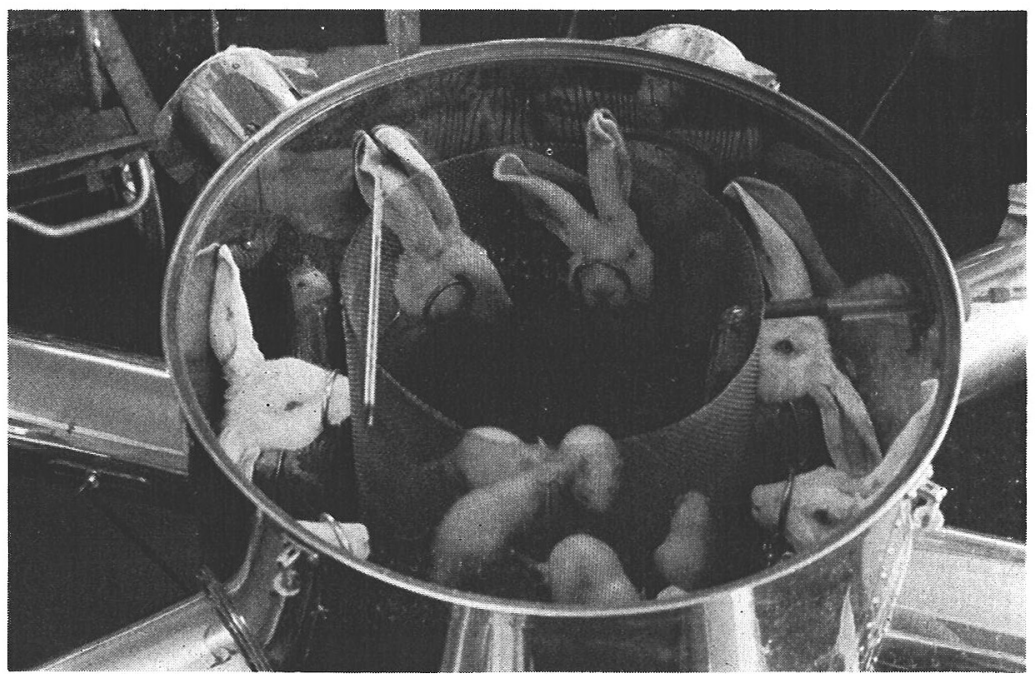

Fig. 1. Instrument used for dust formation and inhalation by rats and rabbits.

coniosis due to such titan dust, the pathogenesis of pulmonary changes caused by this agent was investigated.

\section{Materials AND Methods}

An appropriate dust-forming and inhalation apparatus shown in Fig. 1 was prepared by the author and the titan dust was inhaled by rats and rabbits for 2 to 4 hours a day over a period of 1 to 10 months. The concentrations of the dust in air were measured by a digital dust counter (P-5 type, Shibata Scientific Co., Ltd.) once a week, and the average of these concentrations was calculated. The size distributions of dust particles were also tested.

During the experiments, radiological examinations of the chests of the animals were conducted once a month. Chest radiograms were taken at $35 \mathrm{kV}, 1.5 \mathrm{~mA}$ with an exposure of $0.3 \mathrm{sec}$ in rabbits, and $30 \mathrm{kV}, 1.5 \mathrm{~mA}$ and $0.3 \mathrm{sec}$ exposure in rats.

After the experiments, histopathological examinations of the organs and tissues were made, paying special attention to pulmonary changes. At the same time, large section specimens of the lungs were compared with corresponding chest roentgenograms and any correlations of radiographic shadow nodular foci of titan dusts in the lungs were discussed.

\section{RESULTS}

Experiment 1: Short-term exposure of rats to titan dust: As shown in Table 1, over a period of 30 days, for 4 hours a day, 10 male rats (R1-R10) 
Table 1. Outline of inhalation tests using titan dust rats (Experiment 1).

\begin{tabular}{|c|c|c|c|c|c|}
\hline \multicolumn{3}{|c|}{ Anima!s } & \multirow{2}{*}{$\begin{array}{c}\text { Concentration of } \\
\text { titan dust }\end{array}$} & \multirow{2}{*}{$\begin{array}{l}\text { Period of } \\
\text { inhalation }\end{array}$} & \multirow{2}{*}{ Death or section } \\
\hline & No. & Sex & & & \\
\hline \multirow{2}{*}{ 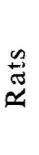 } & R $\quad 1-10$ & male & $\begin{array}{l}63.5-78.8 \mathrm{mg} / \mathrm{m}^{3} \\
\left(70.5 \mathrm{mg} / \mathrm{m}^{3}\right. \\
\text { on average) }\end{array}$ & 30 days & $\begin{array}{l}\text { vivisected on the } \\
\text { day following } \\
\text { inhalation }\end{array}$ \\
\hline & R $11-20$ & "I & Room control & 0 & $" 1$ \\
\hline
\end{tabular}

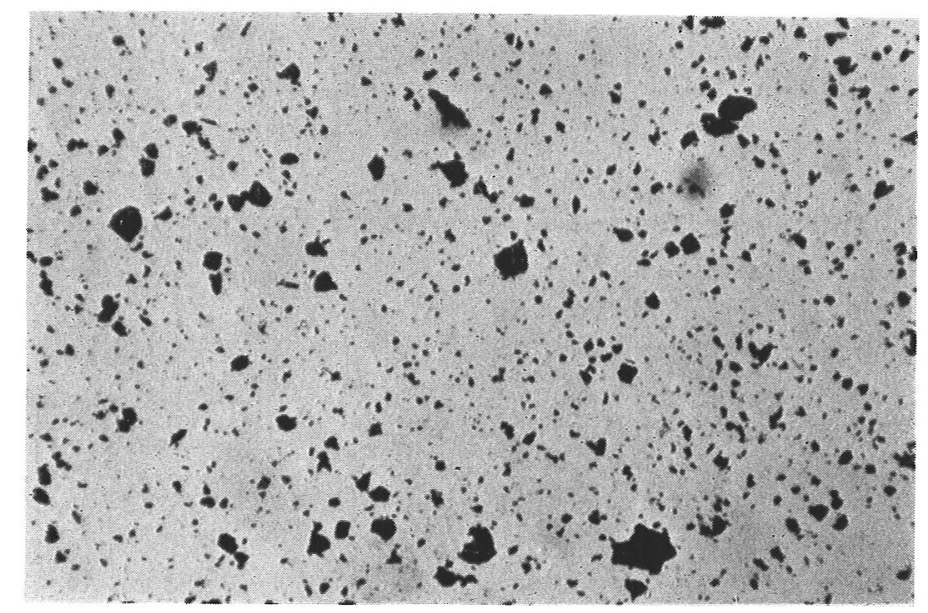

Fig. 2. Micrograph of titanium hydride dust under 325 mesh $(\times 100)$.

were exposed to titan dust, which scattered and accumulated in the workroom environment, and ranged in concentration from 63.5 to $78.8 \mathrm{mg} / \mathrm{m}^{3}\left(70.5 \mathrm{mg} / \mathrm{m}^{3}\right.$ on average). The composition of the dust was $\mathrm{Ti} 48.9 \%$, Fe $17.4 \%$, Si $2.43 \%$, $\mathrm{Mg} 3.91 \%, \mathrm{C} 3.64 \%, \mathrm{Cl} 0.44 \%, \mathrm{~N} 0.42 \%$ and other elements $22.86 \%$. The particle size distribution of the titan dust in the specimens was as follows:

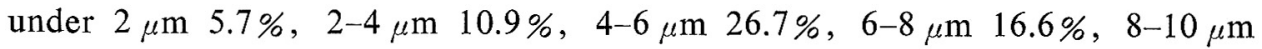
$12.4 \%, \quad 10-12 \mu \mathrm{m} \mathrm{7.2 \% ,} \mathrm{12-14} \mu \mathrm{m} \mathrm{7.2 \% ,} \mathrm{14-16} \mu \mathrm{m} \mathrm{3.7 \% ,} \mathrm{16-18} \mu \mathrm{m} 3.6 \%$, $18-20 \mu \mathrm{m} 1.3 \%$, and over $20 \mu \mathrm{m} 4.5 \%$. As to the histopathological changes in this group, cell infiltration in the alveoli and around blood vessels in the alveoli were noted together with pigmentation, while in other regions of the lung tissues no changes were found, as the 1-month period of exposure was rather short. No histopathological changes were shown in the room control group.

Experiment 2: Exposure of rats and rabbits to titanium hydride dust: The titanium hydride $\left(\mathrm{TiH}_{2}\right)$ was made for the purpose of the inhalation tests and was $99.97 \%$ pure. The microscopical appearance of dust particles below 325 
Table 2. Outline of inhalation tests using titanium hydride $\left(\mathrm{TiH}_{2}\right)$ dust on rats and rabbits (Experiment 2).

\begin{tabular}{|c|c|c|c|c|c|c|}
\hline \multicolumn{3}{|c|}{ Animals } & \multirow{2}{*}{$\begin{array}{c}\text { Concentration of } \\
\mathrm{TiH}_{2} \text { dust }\end{array}$} & \multirow{2}{*}{$\begin{array}{r}\text { Period of } \\
\text { inhalation }\end{array}$} & \multirow{2}{*}{$\begin{array}{l}\text { Period of } \\
\text { survival }\end{array}$} & \multirow{2}{*}{$\begin{array}{l}\text { Death or } \\
\text { section }\end{array}$} \\
\hline & No. & Sex & & & & \\
\hline \multirow[t]{4}{*}{ Rats } & R 21-25 & male & $\begin{array}{c}513-545 \mathrm{mg} / \mathrm{m}^{3} \\
\left(529 \mathrm{mg} / \mathrm{m}^{3}\right. \\
\text { on average })\end{array}$ & 286 days & & vivisected \\
\hline & R 26-30 & " & Room control & & 286 days & "I \\
\hline & R $31-36$ & female & $\begin{array}{c}513-545 \mathrm{mg} / \mathrm{m}^{3} \\
\left(529 \mathrm{mg} / \mathrm{m}^{3}\right. \\
\text { on average })\end{array}$ & 286 days & & "I \\
\hline & R $37-44$ & "I & Room control & & 286 days & " \\
\hline \multirow[t]{4}{*}{ Rabbits } & K 3-6 & male & $\begin{array}{c}513-545 \mathrm{mg} / \mathrm{m}^{3} \\
\left(529 \mathrm{mg} / \mathrm{m}^{3}\right. \\
\text { on average })\end{array}$ & 286 days & & "I \\
\hline & $\begin{array}{r}\text { K } 7-10, \\
16\end{array}$ & "I & Room control & & 286 days & "I \\
\hline & $\begin{array}{r}\text { K 24-26, } \\
28\end{array}$ & female & $\begin{array}{c}513-545 \mathrm{mg} / \mathrm{m}^{3} \\
\left(529 \mathrm{mg} / \mathrm{m}^{3}\right. \\
\text { on average })\end{array}$ & 286 days & & "I \\
\hline & K 29-35 & "I & Room control & & 286 days & "I \\
\hline
\end{tabular}

Table 3. Chest roentgenograms of the rabbits exposed to $\mathrm{TiH}_{2}$.

\begin{tabular}{|c|c|c|c|c|c|c|c|c|}
\hline \multirow{2}{*}{$\begin{array}{l}\text { No. of } \\
\text { animal }\end{array}$} & \multirow[b]{2}{*}{$\operatorname{Sex}$} & \multirow{2}{*}{$\begin{array}{l}\text { Concent- } \\
\text { ration } \\
\text { of } \\
\text { dust }\end{array}$} & \multirow{2}{*}{$\begin{array}{c}\text { Period } \\
\text { of in- } \\
\text { halation }\end{array}$} & \multicolumn{5}{|c|}{$\begin{array}{l}\text { Grade of punctiform opacities by international } \\
\text { classification of radiographs of pneumoconiosis }\end{array}$} \\
\hline & & & & $\begin{array}{c}\text { after } \\
1.5 \\
\text { months }\end{array}$ & $\begin{array}{c}\text { after } \\
5 \\
\text { months }\end{array}$ & $\begin{array}{c}\text { after } \\
6 \\
\text { months }\end{array}$ & $\begin{array}{c}\text { after } \\
7 \\
\text { months }\end{array}$ & $\begin{array}{c}\text { after } \\
8 \\
\text { months }\end{array}$ \\
\hline $\begin{array}{ll}\mathrm{K} & 3 \\
\mathrm{~K} & 4 \\
\mathrm{~K} & 5 \\
\mathrm{~K} & 6\end{array}$ & $\frac{B}{0}$ & 合岕 & No & $\begin{array}{r}0 \\
0 \\
2 \mathrm{p} \\
0\end{array}$ & $\begin{array}{l}3 p \\
2 p \\
3 p \\
1 p\end{array}$ & $\begin{array}{l}3 \mathrm{p} \\
2 \mathrm{p} \\
3 \mathrm{p} \\
1 \mathrm{p}\end{array}$ & $\begin{array}{l}3 p \\
2 p \\
3 p \\
1 p\end{array}$ & $\begin{array}{l}3 p \\
2 p \\
3 p \\
1 p\end{array}$ \\
\hline $\begin{array}{ll}\mathrm{K} & 24 \\
\mathrm{~K} & 25 \\
\mathrm{~K} & 26 \\
\mathrm{~K} & 28\end{array}$ & $\begin{array}{l}\overrightarrow{0} \\
\stackrel{0}{0} \\
0\end{array}$ & 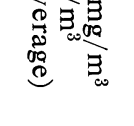 & 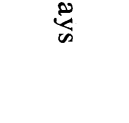 & $\begin{array}{l}0 \\
0 \\
0 \\
0\end{array}$ & $\begin{array}{l}\text { died } \\
2 p \\
1 p \\
1 p\end{array}$ & $\begin{array}{l}2 p \\
1 p \\
1 p\end{array}$ & $\begin{array}{c}2 \mathrm{p} \\
\text { died } \\
1 \mathrm{p}\end{array}$ & $\begin{array}{l}2 p \\
1 p\end{array}$ \\
\hline
\end{tabular}

mesh in size is shown in Fig. 2. As shown in Table 2, the titanium hydride dust was inhaled 4 hours a day for 2 months, by 5 male rats (R21-R25) and 6 female rats (R31-R36), and for 8 months by 4 male rabbits (K3-K6) and 4 female rabbits (K24-K28). The particle size distribution of the dust was as follows:

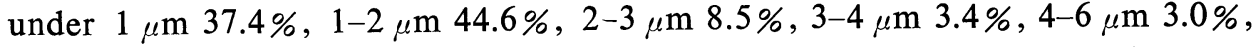
and $6-23 \mu \mathrm{m} 3.1 \%$. The dust particles under $2 \mu \mathrm{m}$ in size accounted for $82 \%$ of the total, as shown in Fig. 3. The concentration of the dust in air was 


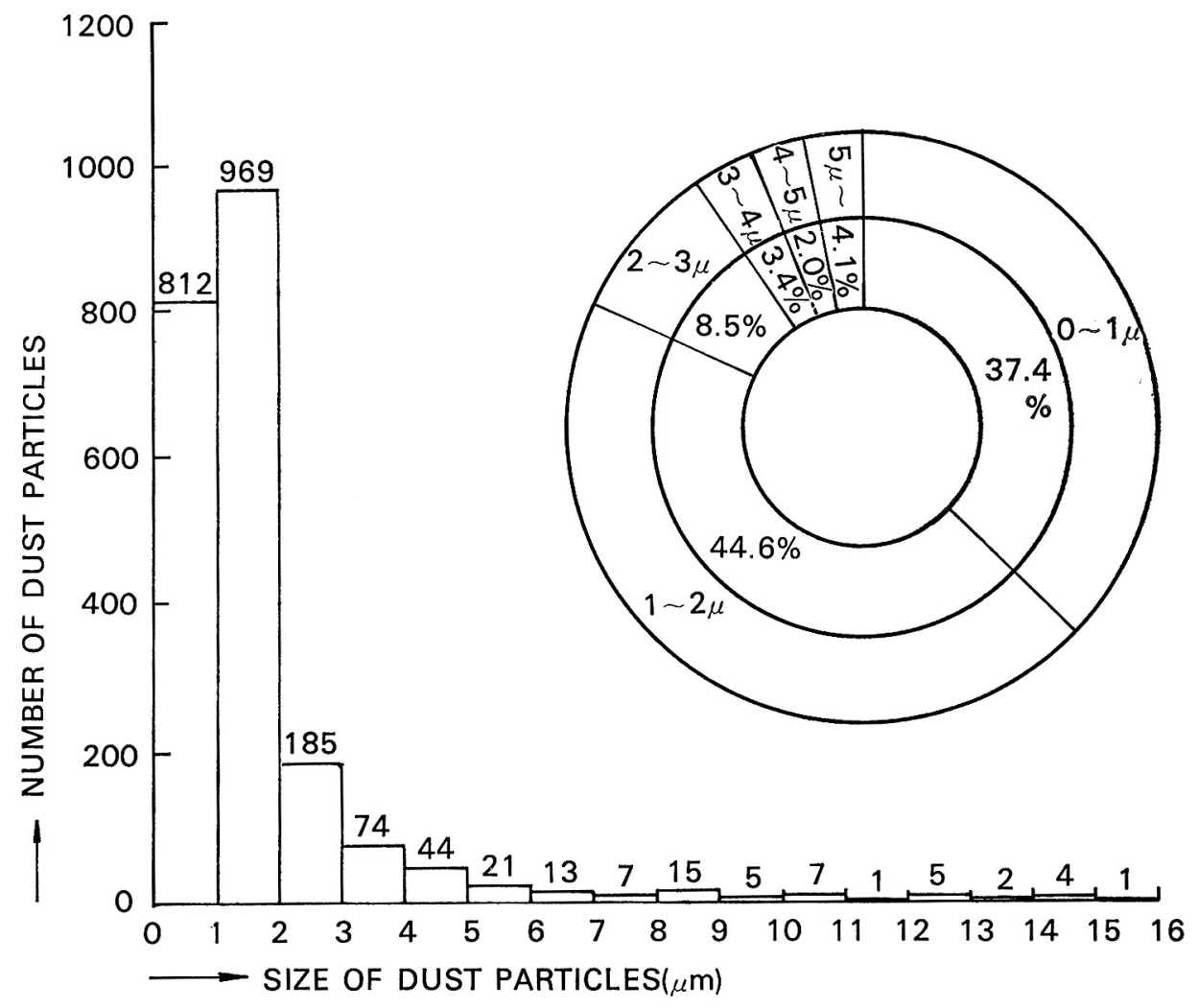

Fig. 3. Distribution of dust particles of titanium hydride under 325 mesh.

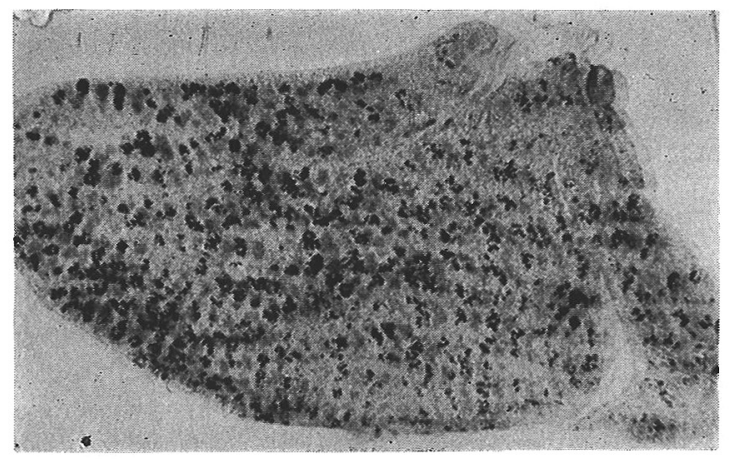

Fig. 4. Fine dust particles deposited in the lung of rabbit "K5" are shown in this large section specimen (unstained).

$513-545 \mathrm{mg} / \mathrm{m}^{3}$, or $529 \mathrm{mg} / \mathrm{m}^{3}$ on average.

The findings of the chest roentgenograms of the rabbits are classified according to the international classification of radiographs ${ }^{3}$ ) for pneumoconiosis, and 


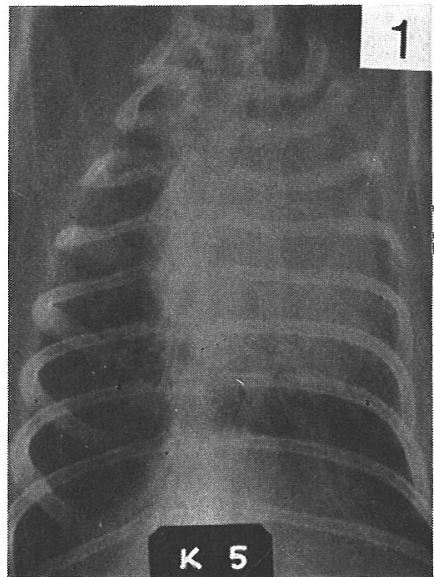

1.5 months after the beginning of inhalation (March 2, 1966)

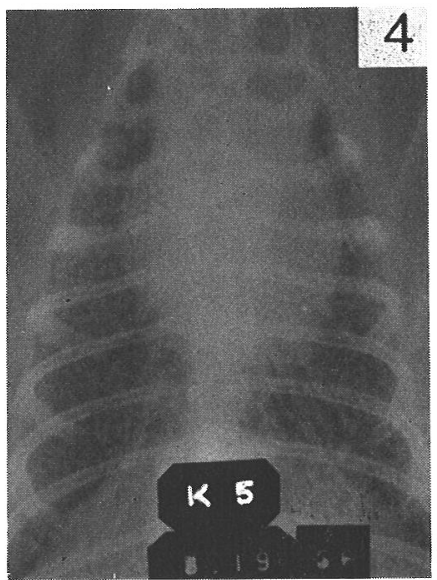

7 months after

(August 19, 1966)

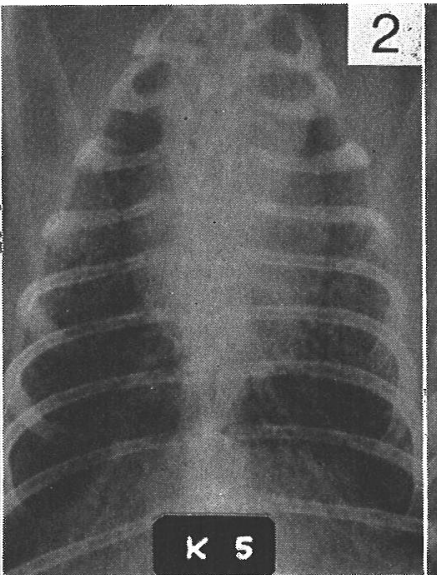

5 months after

(June 20, 1966)

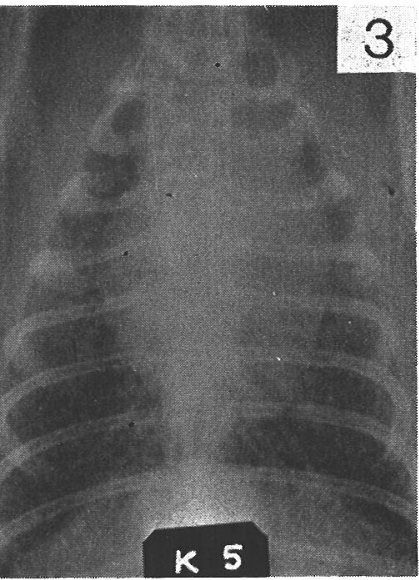

6 months after

(July 21, 1966)

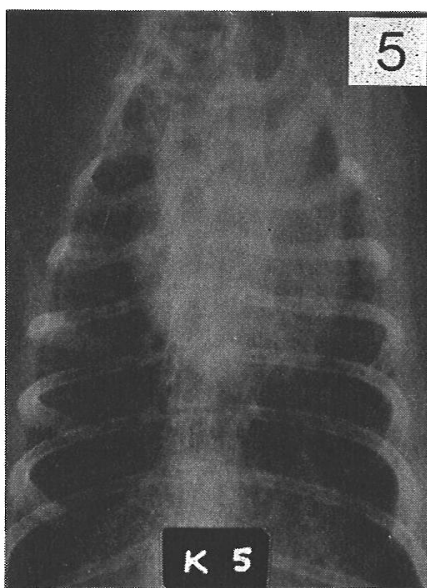

8 months after

(September 16, 1966)

Fig. 5. Monthly changes in chest roentgenograms of the rabbit "K5" exposed to $\mathrm{TiH}_{2}$ dust below 325 mesh in Experiment 2.

are shown in Table 3.

Chest radiograms of the rabbits, after 5 months, revealed reticulonodular shadowing of categories $1 p$ to $2 p$, and occasionally $3 p$. This nodular opacity may have resulted from titan dust as shown in the large section specimen of the lung of rabbit "K5" (Fig. 4). The monthly changes in the chest roentgenograms of rabbit "K5" with lapse of time are shown in Fig. 5.

Histopathologically, some changes were found in bronchioli, lungs and lymph nodes. As a whole, there was a remarkable accumulation of phagocytes and macrophages in alveoli, proliferation of connective tissues in the alveolar walls, forma- 


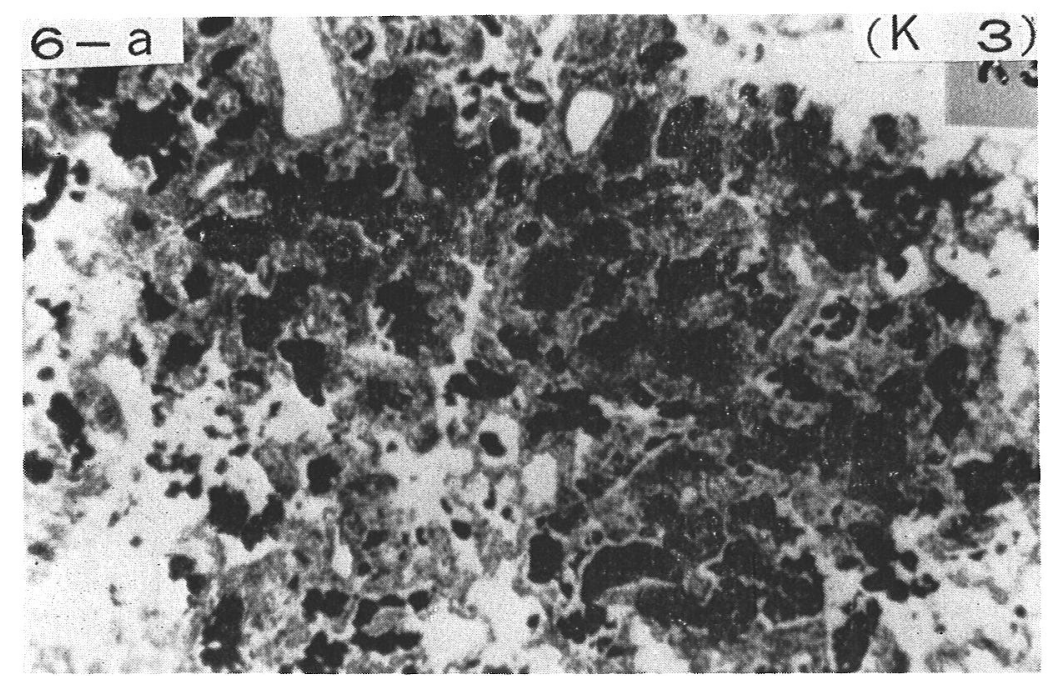

Fig. 6-a. (K3) (Azan-Malloy stain) $(\times 80)$

Irreversible dust foci, with proliferation of alveolar wall epithelial cells and connective tissue cells within the alveoli.

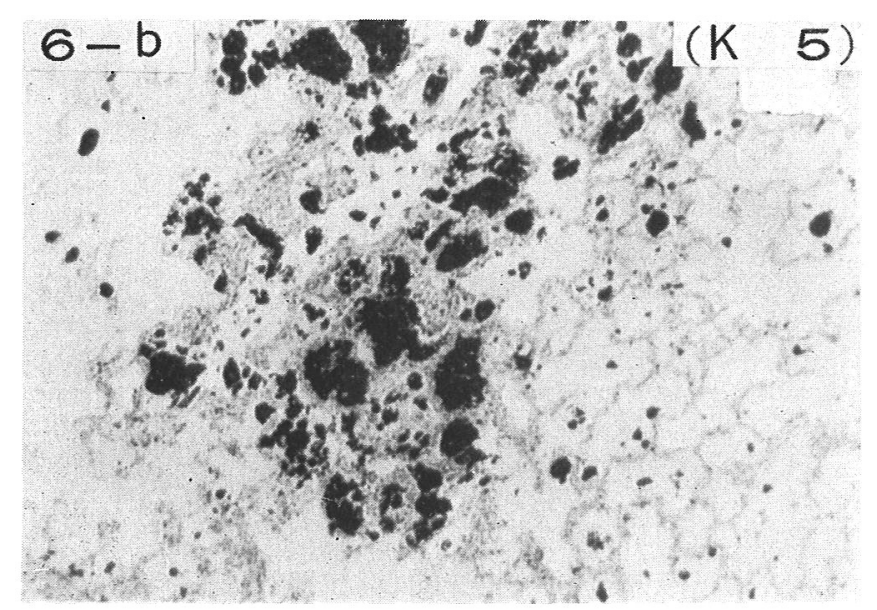

Fig. 6-b. (K5) (hematoxylin and eosin stain) $(\times 60)$

Irreversible dust foci, with proliferation of alveolar wall epithelial cells and connective tissue cells within the alveoli.

tion of irreversible dust foci, and dust retention in the lymph nodes. Hyperplasia of fibroblasts, however, was not remarkable. As for histopathological changes, the relevant micrographs are shown in Fig. 6(a-d). From these facts, the possibility of occurrence of pneumoconiosis as a result of titan dust inhalation as well as by carbon and iron dioxide was concluded. 


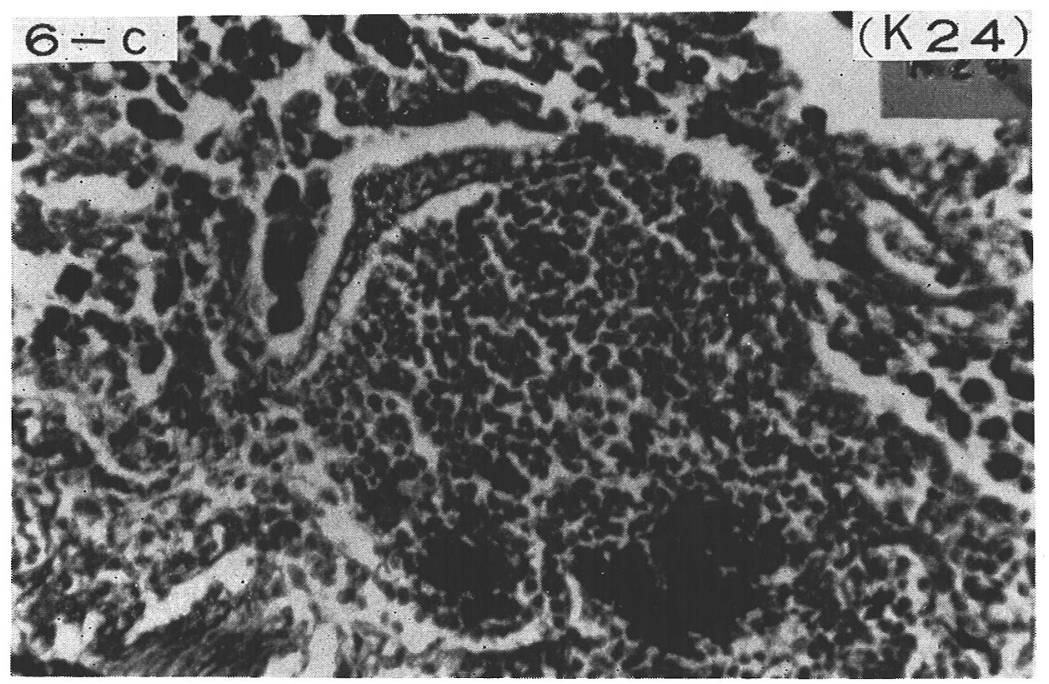

Fig. 6-c. (K24) (Azan-Mallory stain) $(\times 200)$

Titan dust particles evident in the bronchial gland.

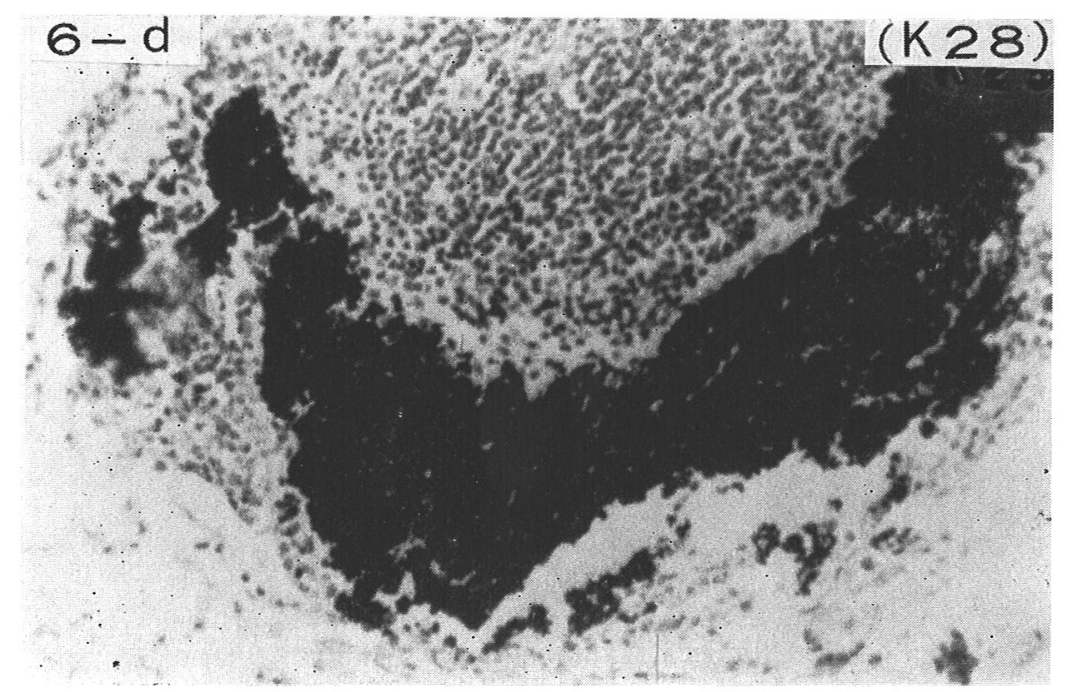

Fig. 6-d. (K28) (hematoxylin and eosin stain) $(\times 150)$

Phagocytes within the alveoli, together with proliferation of connective tissue cells within the alveolar walls, and dust particles.

Experiment 3: Inhalation tests with titan dust (under $200 \mathrm{mesh}$ ) in rats and rabbits: As shown in Table 4, titan dust under $200 \mathrm{mesh}$, which scattered and accumulated in the workroom environment and was composed of $\mathrm{Ti} 48.0 \%, \mathrm{Fe}$ $19.4 \%, \mathrm{Mg} 6.23 \%$, Si $1.31 \%, \mathrm{Mn} 0.11 \%, \mathrm{C}, \mathrm{N}, \mathrm{Cl}$ and other trace elements, 
Table 4. Outline of inhalation tests using titan dust (under 200 mesh) on rats and rabbits (Experiment 3 ).

\begin{tabular}{|c|c|c|c|c|c|c|}
\hline \multicolumn{3}{|c|}{ Animals } & \multirow{2}{*}{$\begin{array}{l}\text { Concentration } \\
\text { of titan dust }\end{array}$} & \multirow{2}{*}{$\begin{array}{l}\text { Period of } \\
\text { inhalation }\end{array}$} & \multirow{2}{*}{$\begin{array}{l}\text { Period of } \\
\text { observation }\end{array}$} & \multirow{2}{*}{$\begin{array}{l}\text { Death or } \\
\text { section }\end{array}$} \\
\hline \multirow{3}{*}{ 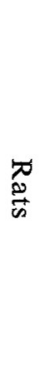 } & No. & Sex & & & & \\
\hline & $\begin{array}{ll}\mathrm{R} & 45 \\
\mathrm{R} & 46 \\
\mathrm{R} & 47 \\
\mathrm{R} & 48 \\
\mathrm{R} & 50 \\
\mathrm{R} & 55 \\
\mathrm{R} & 57 \\
\mathrm{R} & 58 \\
\mathrm{R} & 62\end{array}$ & 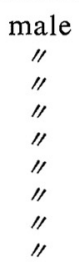 & $\begin{array}{c}22.4 \mathrm{mg} / \mathrm{m}^{3} \\
\text { " } \\
\text { " } \\
\text { " } \\
\text { " } \\
\text { " } \\
\text { " } \\
\text { " } \\
\text { " }\end{array}$ & $\begin{array}{c}10 \text { months } \\
\text { " } \\
\text { " } \\
\text { " } \\
\text { " } \\
\text { " } \\
\text { " } \\
\text { " }\end{array}$ & $\begin{array}{c}6 \text { months } \\
\text { " } \\
\text { " } \\
\text { " } \\
\text { " } \\
\text { "I } \\
\text { "I } \\
\text { " } \\
\text { "I }\end{array}$ & $\begin{array}{c}\text { died } \\
\text { vivisected } \\
\text { died } \\
\text { vivisected } \\
\text { "/ } \\
\text { "I } \\
\text { "/ } \\
\text { "I } \\
\text { died }\end{array}$ \\
\hline & R 63-76 & 11 & Room control & & 20 months & vivisected \\
\hline \multirow[t]{2}{*}{ 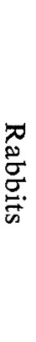 } & $\begin{array}{ll}\mathrm{K} & 12 \\
\mathrm{~K} & 36 \\
\mathrm{~K} & 37 \\
\mathrm{~K} & 38 \\
\mathrm{~K} & 39 \\
\mathrm{~K} & 40 \\
\mathrm{~K} & 41 \\
\mathrm{~K} & 42 \\
\mathrm{~K} & 43\end{array}$ & $\begin{array}{l}\text { "1 } \\
11 \\
1 " \\
11 \\
1 " \\
11 \\
11 \\
11 \\
11\end{array}$ & 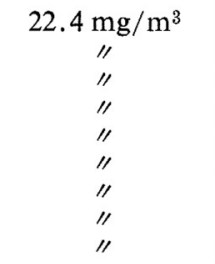 & $\begin{array}{l}7.5 \text { months } \\
10 \\
7 \\
10 \\
2.5 \\
10 \\
8 \\
10 \\
10\end{array}$ & $\begin{array}{l}4 \text { months } \\
13 \\
0 \\
13 \\
10 \\
15 \\
0 \\
7 \\
7\end{array}$ & $\begin{array}{l}\text { died } \\
\text { vivisected } \\
\text { died } \\
\text { vivisected } \\
\text { died } \\
\text { vivisected } \\
\text { died } \\
\text { vivisected } \\
\text { // }\end{array}$ \\
\hline & K $\begin{array}{l}22 \\
44\end{array}$ & 11 & Room control & & 18 months & vivisected \\
\hline
\end{tabular}

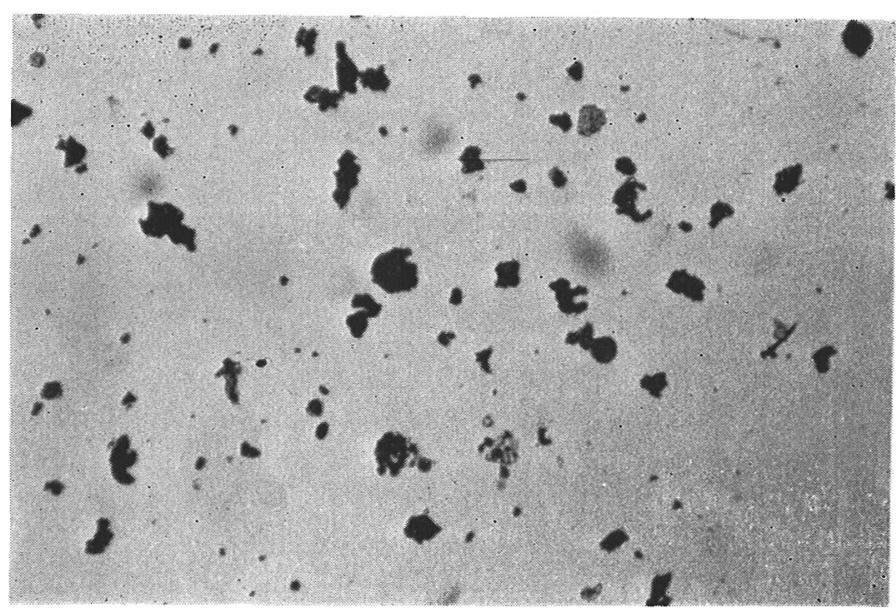

Fig. 7. Micrograph of dust particles under 200 mesh scattered and accumulated in the workroom environment $(\times 100)$.

was inhaled by 9 male rats (R45-R62) and 8 male rabbits (K36-K43) for 7 to 10 months at 2 hours per day. The average concentration of dust in the air was $22.4 \mathrm{mg} / \mathrm{m}^{3}$. The microscopic appearance of the dust is shown in 
Fig. 7. The particle size distribution of the dust was as follows: under $1 \mu \mathrm{m}$

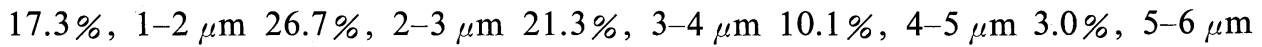
$2.4 \%$, and over $6 \mu \mathrm{m} 19.2 \%$.

After the experiments, surviving animals were observed for the next 15 months. According to monthly radiological examination of the chests of the animals, after 4 to 5 months in rabbits, radiographic findings of category $1 \mathrm{p}$ were seen, and thereafter category $2 p$ or $3 p$ was found. In rats, however, $1 p$ was seen after 6 months, $2 p$ was seen after 8 to 10 months, but no findings of $3 p$ were found even after 17 months following dust exposure.

Histopathologically, however, remarkable numbers of phagocytes and macrophages containing absorbed dust particles were seen in rabbits, together with proliferation of epithelial cells, hyperplasia of connective tissues in the alveolar wall, and formation of irreversible dust foci. In rats, the same features were observed, but the amount of titan dust in the tissues and cells was less than in rabbits.

Experiment 4: Inhalation tests of fine titan dust (under 325 mesh) at high concentration: As shown in Table 5, fine titan dust under 325 mesh was inhaled by 9 male rats (R77-R90) and 8 male rabbits (K45-K52) for 4 hours a day over a period of 7 months, at an average concentration of $476 \mathrm{mg} / \mathrm{m}^{3}$, and the surviving animals were then observed for 6 months. Monthly radiological examinations of the chest were made. In rabbits, after 1 to 3 months, nodular shadows

Table 5. Outline of inhalation tests using fine titan dust (under 325 mesh) on rats and rabbits (Experiment 4 ).

\begin{tabular}{|c|c|c|c|c|c|c|}
\hline \multicolumn{3}{|c|}{ Animals } & \multirow{2}{*}{$\begin{array}{l}\text { Concentration } \\
\text { of titan dust }\end{array}$} & \multirow{2}{*}{$\begin{array}{l}\text { Period of } \\
\text { inhalation }\end{array}$} & \multirow{2}{*}{$\begin{array}{l}\text { Period of } \\
\text { observation }\end{array}$} & \multirow{2}{*}{$\begin{array}{l}\text { Death or } \\
\text { section }\end{array}$} \\
\hline & No. & Sex & & & & \\
\hline $\begin{array}{l}\pi_{n} \\
\stackrel{\omega}{\infty}\end{array}$ & $\begin{array}{ll}\mathrm{R} & 77 \\
\mathrm{R} & 78 \\
\mathrm{R} & 79 \\
\mathrm{R} & 80 \\
\mathrm{R} & 84 \\
\mathrm{R} & 86 \\
\mathrm{R} & 88 \\
\mathrm{R} & 89 \\
\mathrm{R} & 90\end{array}$ & $\begin{array}{l}\text { male } \\
\text { " } \\
\text { " } \\
\text { " } \\
\text { " } \\
\text { " } \\
\text { " } \\
\text { " }\end{array}$ & $\begin{array}{c}476 \mathrm{mg} / \mathrm{m}^{3} \\
\text { " } \\
\text { " } \\
\text { " } \\
\text { " } \\
\text { " } \\
\text { " } \\
\text { " }\end{array}$ & $\begin{array}{l}7 \\
7 \\
7 \\
6.5 \\
7 \\
7 \\
7 \\
7 \\
7\end{array}$ & $\begin{array}{l}6.5 \text { months } \\
8 \\
5.5 \\
0 \\
4 \\
3 \\
7.5 \\
5.5 \\
4\end{array}$ & $\begin{array}{c}\text { died } \\
\text { vivisected } \\
\text { died } \\
\text { " } \\
\text { " } \\
\text { " } \\
\text { vivisected } \\
\text { died } \\
\text { " }\end{array}$ \\
\hline \multirow[t]{2}{*}{ 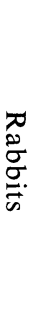 } & $\begin{array}{ll}\mathrm{K} & 45 \\
\mathrm{~K} & 46 \\
\mathrm{~K} & 47 \\
\mathrm{~K} & 48 \\
\mathrm{~K} & 49 \\
\mathrm{~K} & 50 \\
\mathrm{~K} & 51 \\
\mathrm{~K} & 52\end{array}$ & $\begin{array}{l}\text { "1 } \\
\text { "1 } \\
1 " \\
1 " \\
\text { "1 } \\
\text { " }\end{array}$ & $\begin{array}{l}\text { "1 } \\
\text { "1 } \\
\text { ", } \\
\text { ", } \\
\text { " }\end{array}$ & $\begin{array}{l}7 \\
7 \\
7 \\
7 \\
4.5 \\
7 \\
7 \\
7 \\
7\end{array}$ & $\begin{array}{ll}6 & \text { months } \\
6 & \\
6 & \\
4 & \\
0 & \\
6 & \\
6 & \\
6 & \end{array}$ & $\begin{array}{c}\text { vivisected } \\
\text { " } \\
\text { "' } \\
\text { died } \\
\text { " } \\
\text { vivisected } \\
\text { " } \\
\text { " }\end{array}$ \\
\hline & $\begin{array}{c}\mathrm{K} \\
53- \\
56\end{array}$ & " & "1 & & 13 months & "1 \\
\hline
\end{tabular}




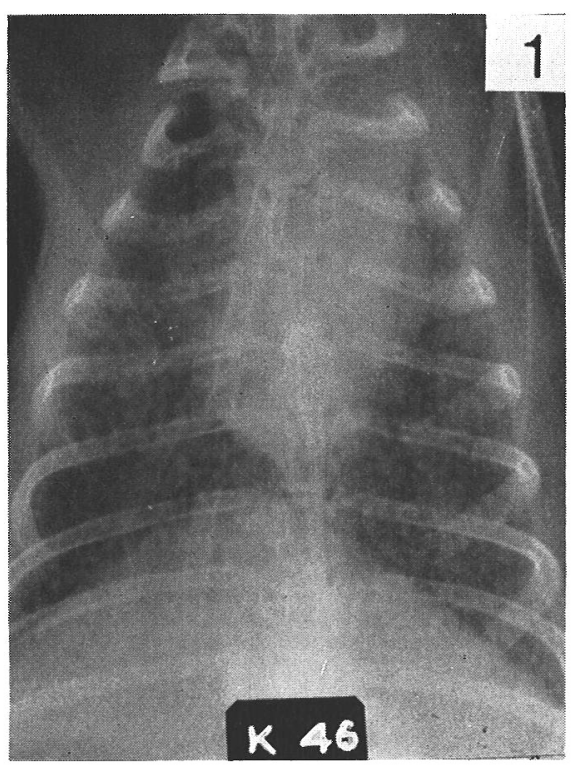

K 46:

8 months after the beginning of inhalation

(February 12, 1969)

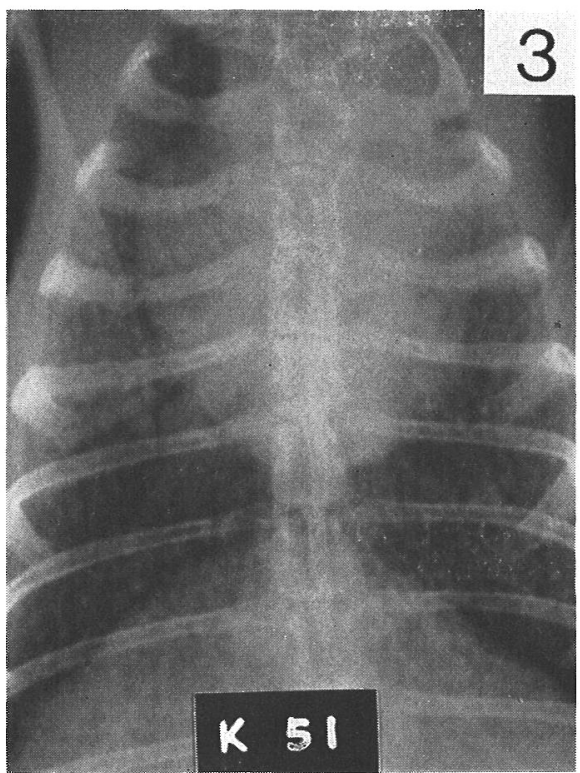

K 51 :

6 months after

(December 4, 1968)

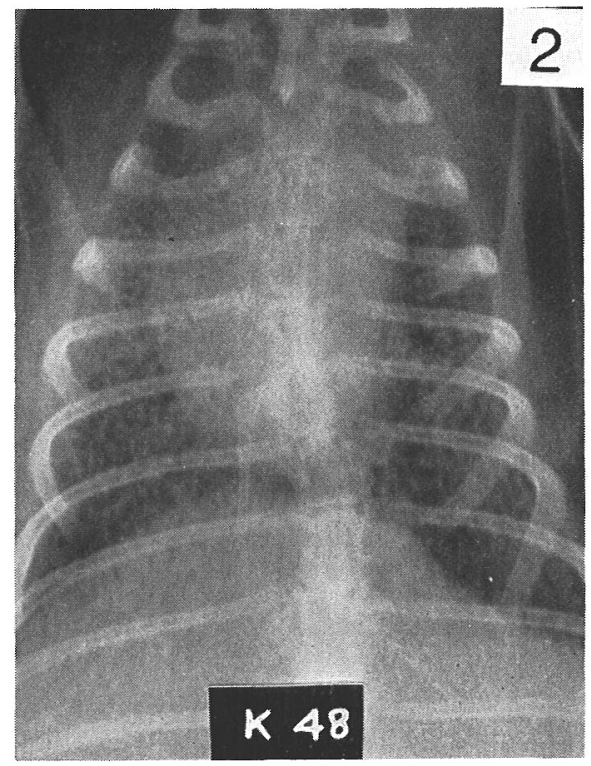

K 48:

6 months after

(December 4, 1968)

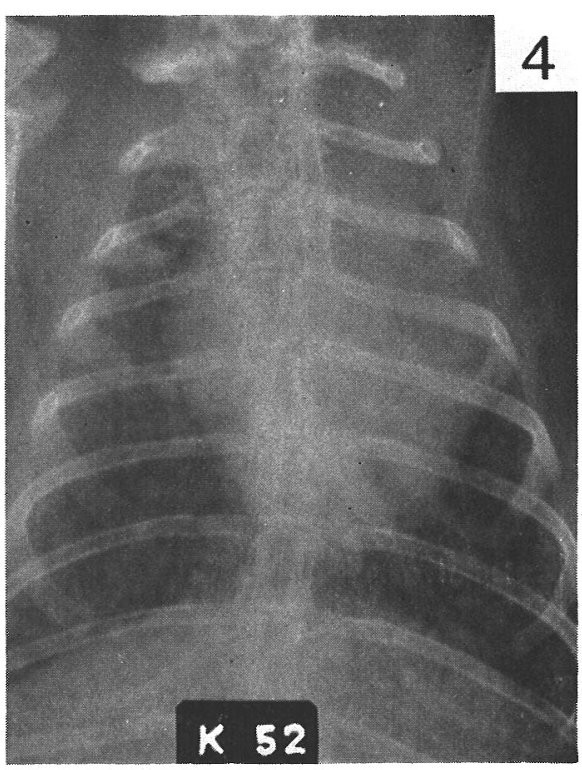

K 52:

20 months after

(February 23, 1970)

Fig. 8. Chest roentgenograms of the nodular shadows of rabbits exposed to fine titan dust below 200 mesh in Experiment 4. 


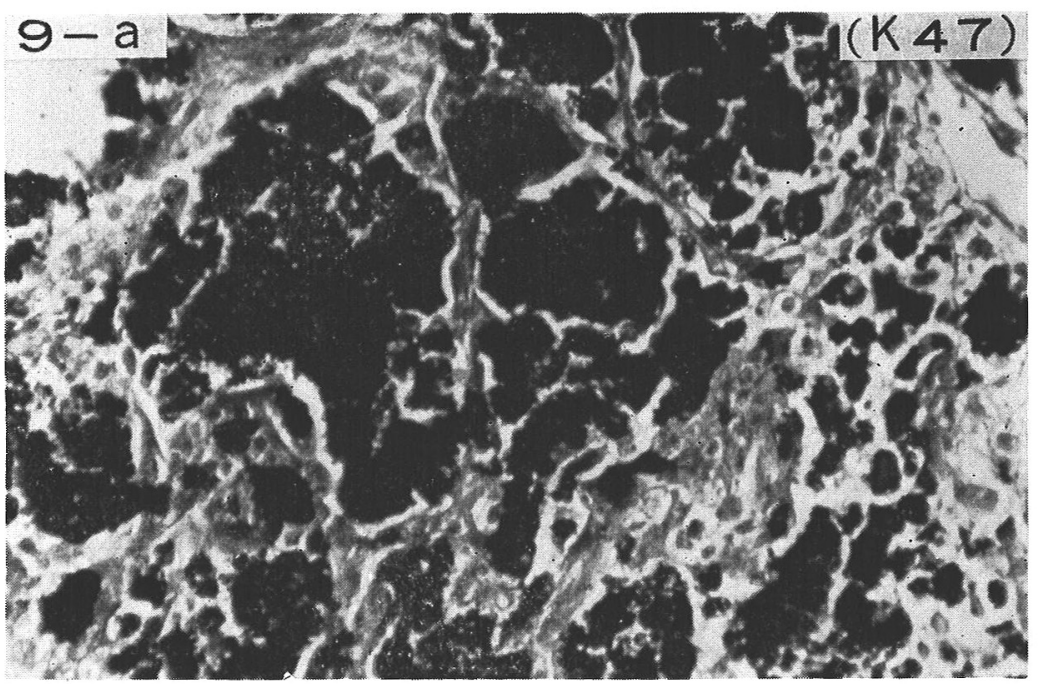

Fig. 9-a. (K47) (hematoxylin and eosin stain) $(\times 200)$

Titan dust particles both inside and outside cells, together with infiltration of small round cells and fibroblasts within the alveolar walls, where dust cells are densely present, making the wall thick.

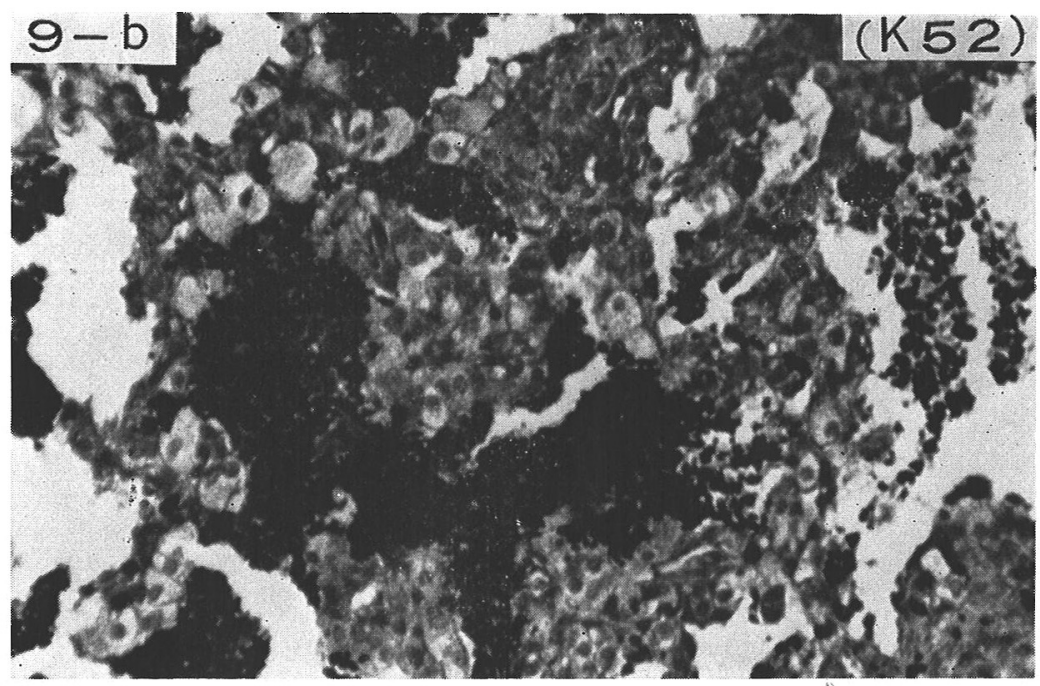

Fig. 9-b. (K52) (hematoxylin and eosin stain) $(\times 200)$

Dense presence of titan dust particles within the alveoli, associated with proliferation of small round cells, fibroblasts, histiocytes and monocytes within the alveolar walls, and marked cellular reaction. 
Table 6. Outline of intratracheal infusion of titanium hydride dust for rats (Experiment 5).

\begin{tabular}{|c|c|c|c|c|}
\hline \multicolumn{2}{|c|}{ Rats } & \multirow{2}{*}{$\begin{array}{l}\text { Concentration of } \\
\text { dust and volume }\end{array}$} & \multirow{2}{*}{$\begin{array}{l}\text { Period of survival } \\
\text { and observation }\end{array}$} & \multirow{2}{*}{$\begin{array}{l}\text { Death or } \\
\text { section }\end{array}$} \\
\hline No. & Sex & & & \\
\hline $\begin{array}{lr}\mathrm{R} & 96 \\
\mathrm{R} & 97 \\
\mathrm{R} & 98 \\
\mathrm{R} & 99 \\
\mathrm{R} & 100 \\
\mathrm{R} & 101 \\
\mathrm{R} & 102 \\
\mathrm{R} & 103 \\
\mathrm{R} & 104 \\
\mathrm{R} & 105\end{array}$ & $\begin{array}{c}\text { male } \\
\text { "1 } \\
\text { "1 } \\
\text { " } \\
\text { " } \\
\text { "1 } \\
\text { "1 }\end{array}$ & $\begin{array}{c}10 \mathrm{mg} \text { in } 1 \mathrm{ml} \\
\text { "1 } \\
\text { " } \\
\text { " } \\
\text { " } \\
\text { " } \\
\text { " } \\
\text { " } \\
\text { " }\end{array}$ & $\begin{array}{l}380 \text { days } \\
485 \\
486 \\
486 \\
486 \\
486 \\
287 \\
486 \\
482 \\
483\end{array}$ & $\begin{array}{c}\text { died } \\
\text { vivisected } \\
\text { "I } \\
\text { " } \\
\text { " } \\
\text { died } \\
\text { vivisected } \\
\text { " } \\
\text { " }\end{array}$ \\
\hline $\begin{array}{ll}R & 106 \\
R & 107 \\
R & 108 \\
R & 109 \\
R & 110 \\
R & 111 \\
R & 112 \\
R & 113 \\
R & 114 \\
R & 115\end{array}$ & $\begin{array}{l}\text { " } \\
\text { " } \\
\text { "1 } \\
\text { " } \\
\text { " } \\
\text { " } \\
\text { " } \\
\text { " }\end{array}$ & $\begin{array}{c}50 \mathrm{mg} \text { in } 1 \mathrm{ml} \\
\text { " } \\
\text { " } \\
\text { " } \\
\text { " } \\
\text { " } \\
\text { " } \\
\text { " }\end{array}$ & $\begin{array}{l}468 \\
480 \\
482 \\
485 \\
480 \\
482 \\
485 \\
485 \\
479 \\
480\end{array}$ & $\begin{array}{c}\text { died } \\
\text { vivisected } \\
\text { "I } \\
\text { " } \\
\text { " } \\
\text { " } \\
\text { " } \\
\text { "1 } \\
\text { " }\end{array}$ \\
\hline $\begin{array}{ll}\mathrm{R} & 116 \\
\mathrm{R} & 117 \\
\mathrm{R} & 118 \\
\mathrm{R} & 119 \\
\mathrm{R} & 120 \\
\mathrm{R} & 121 \\
\mathrm{R} & 122 \\
\mathrm{R} & 123 \\
\mathrm{R} & 124 \\
\mathrm{R} & 125\end{array}$ & $\begin{array}{l}\text { " } \\
\text { "1 } \\
\text { ", } \\
\text { " } \\
\text { " } \\
\text { "1 } \\
\text { " }\end{array}$ & $\begin{array}{c}100 \mathrm{mg} \text { in } 1 \mathrm{ml} \\
\text { "1 } \\
\text { " } \\
\text { " } \\
\text { " } \\
\text { " } \\
\text { " }\end{array}$ & $\begin{array}{r}486 \\
485 \\
486 \\
10 \\
483 \\
484 \\
486 \\
480 \\
463 \\
464\end{array}$ & $\begin{array}{l}\text { vivisected } \\
\text { " } \\
\text { died } \\
\text { vivisected } \\
\text { " } \\
\text { " } \\
\text { "' } \\
\text { " }\end{array}$ \\
\hline $\begin{array}{ll}R & 126 \\
R & 127 \\
R & 128 \\
R & 129 \\
R & 130 \\
R & 131 \\
R & 132 \\
R & 133 \\
R & 134\end{array}$ & $\begin{array}{l}\text { "1 } \\
\text { " } \\
\text { "' } \\
\text { " } \\
\text { "' } \\
\text { " }\end{array}$ & $\begin{array}{c}500 \mathrm{mg} \text { in } 1 \mathrm{ml} \\
\text { " } \\
\text { " } \\
\text { " } \\
\text { " } \\
\text { " } \\
\text { " }\end{array}$ & $\begin{array}{r}16 \\
84 \\
10 \\
336 \\
484 \\
482 \\
484 \\
480 \\
483\end{array}$ & $\begin{array}{c}\text { died } \\
\text { " } \\
\text { " } \\
\text { vivisected } \\
\text { " } \\
\text { "' } \\
\text { " }\end{array}$ \\
\hline $\begin{array}{ll}\text { R } & 135 \\
R & 136 \\
R & 137 \\
R & 138 \\
R & 139 \\
R & 140 \\
R & 141 \\
R & 142 \\
R & 143 \\
R & 144\end{array}$ & 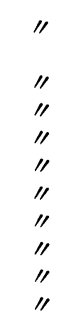 & $\begin{array}{c}\text { Control } \\
(0 \mathrm{mg} \text { in } 1 \mathrm{ml}) \\
\text { " } \\
\text { " } \\
\text { " } \\
\text { " } \\
\text { " } \\
\text { " } \\
\text { " } \\
\text { " } \\
\text { " }\end{array}$ & $\begin{array}{r}486 \\
\\
486 \\
8 \\
486 \\
486 \\
486 \\
486 \\
486 \\
11 \\
486\end{array}$ & $\begin{array}{l}\text { vivisected } \\
\text { died } \\
\text { vivisected } \\
\prime \prime \\
\prime \prime \\
\prime \prime \\
\text { died } \\
\text { vivisected }\end{array}$ \\
\hline
\end{tabular}




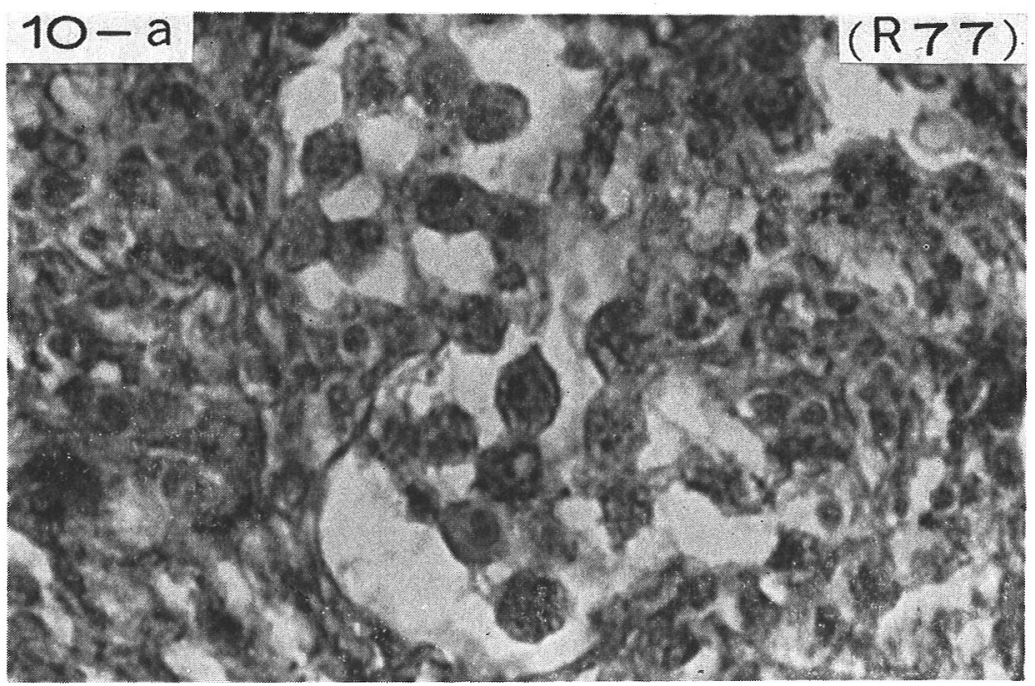

Fig. 10-a. (R97) (hematoxylin and eosin stain) $(\times 400)$

Many dust cells containing fine dust particles with in pulmonary alveoli, together with lymphocytes, phagocytes and polynuclear leukocytes deposited within the alveoli and alveolar walls.

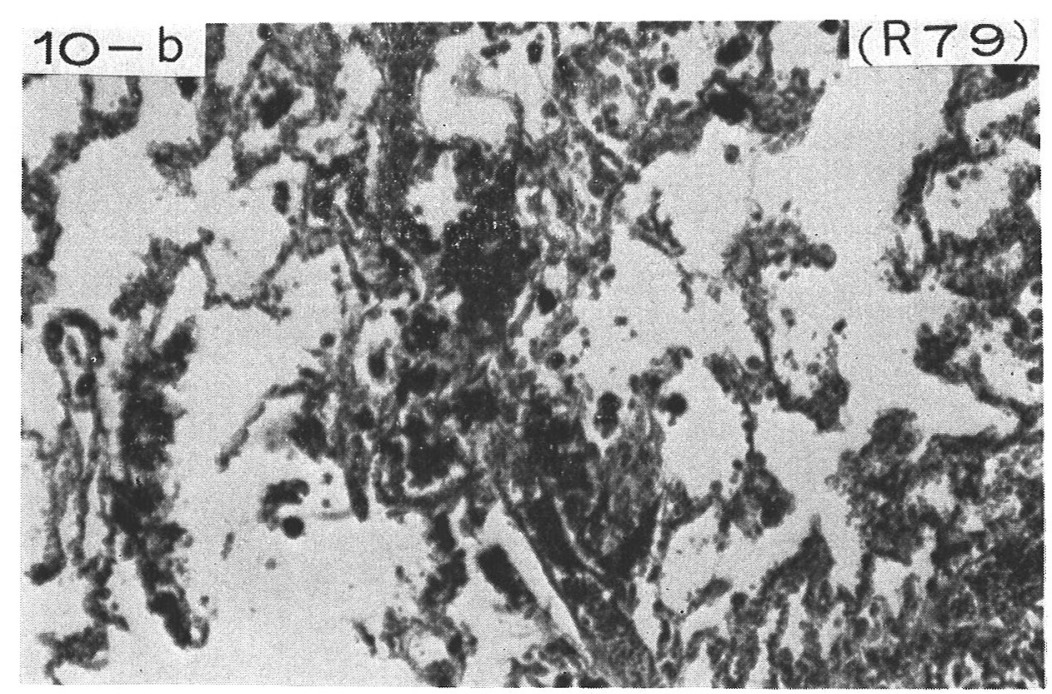

Fig. 10-b. (R99) (hematoxylin and eosin stain) $(\times 100)$

Large titan dust particles deposited within neighboring alveoli. Infiltration of phagocytes, round cells and fibroblasts is observed around the blood vessel and within the alveolar walls. 


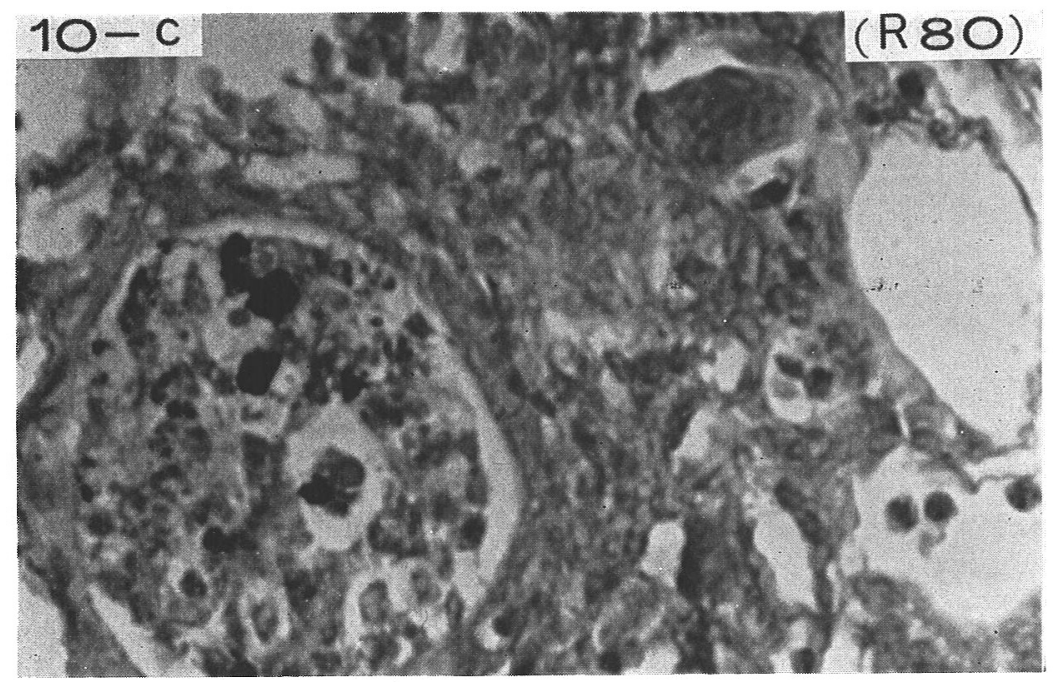

Fig. 10-c. (R100) (hematoxylin and eosin stain) $(\times 400)$

Dust cells and giant cells containing foreign material can be seen within the alveoli around the bronchioli.

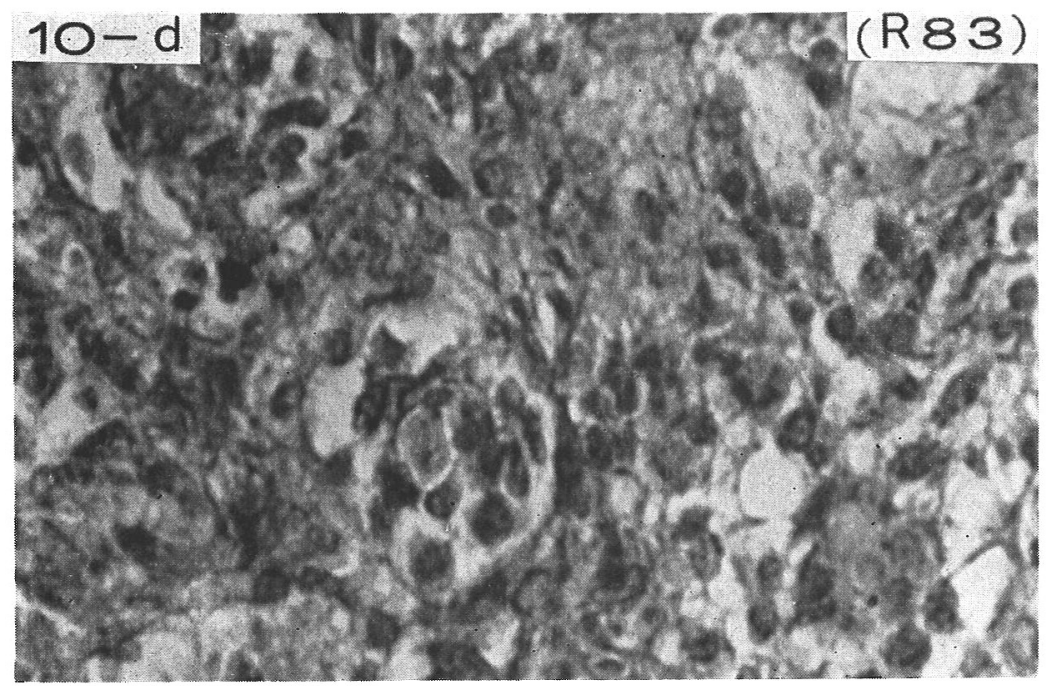

Fig. 10-d. (R103) (hematoxylin and eosin stain) $(\times 400)$

Dense clustering of dust cells within the alveoli, and dust cells showing partial vacuolization. Round cells and fibroblasts are present between the dust cells.

of category $1 p$ were seen, $2 p$ and $3 p$ appearing after 2 to 4 months and after 3 to 6 months, respectively. Radiologically in rats, after 3 to 5 months $1 \mathrm{p}$, and after 4 to 5 months $2 p$ were revealed, but even after 15 months no findings of $3 p$ occurred. The chest roentgenograms showing the nodular shadows of rabbits 


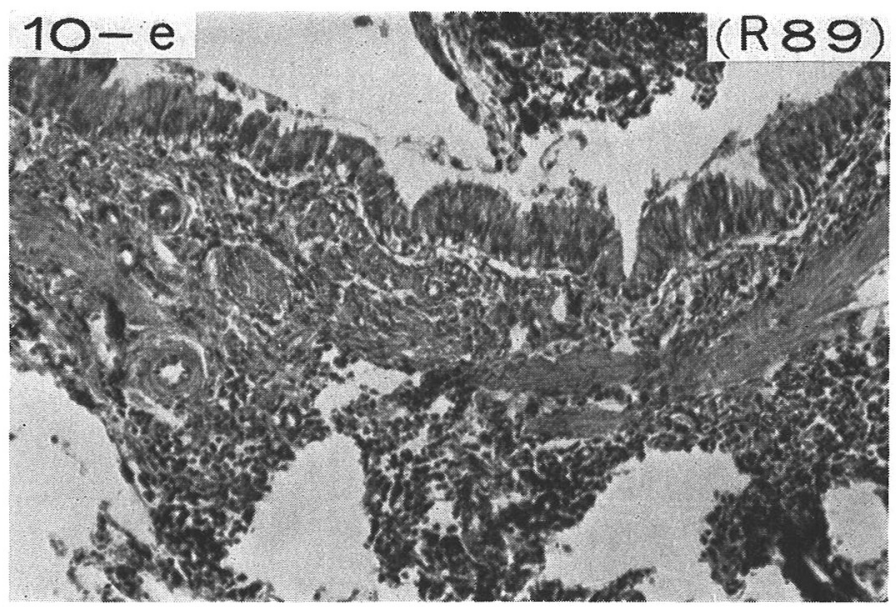

Fig. 10-e. (R109) (hematoxylin and eosin stain) $(\times 400)$

Nodes of dust cells presert in the tissues around the blood vessels. Dust cells appear with giant cells partly full of foreign material. Infilration of fibroblasts and small round cells can be observed between the dust cells.

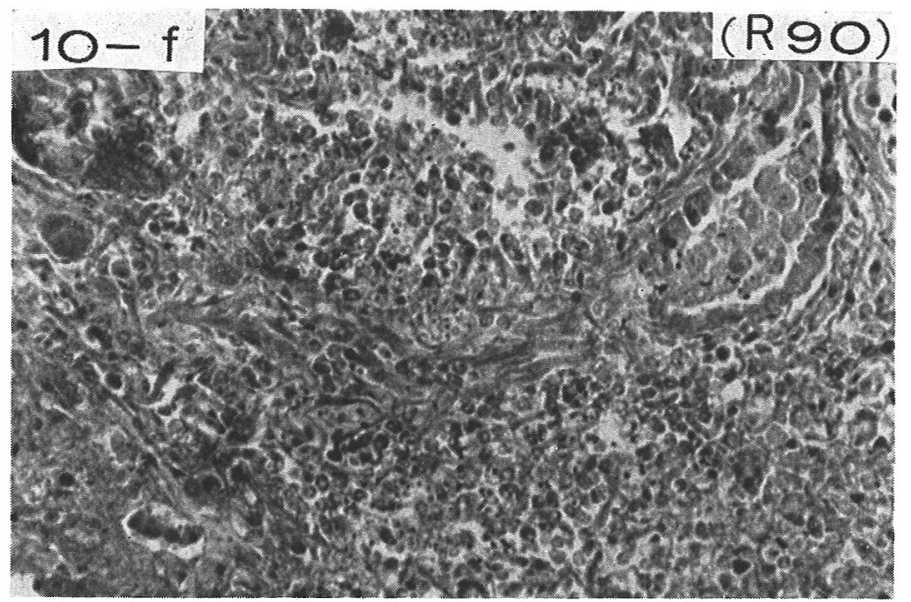

Fig. 10-f. (R110) (hematoxylin and eosin stain) $(\times 200)$

Infiltration of dust particles within the tissue around the blood vessels. Dust cells appear densely within the alveoli, with giant cells containing foreign material. Infiltration of fibroblasts and small round cells can be observed between the dust cells.

exposed to the fine titan dust under 325 mesh used in this experiment are shown in Fig. 8.

Histopathologically, however, retention of the fine titan dust in alveoli and lymph nodes, proliferation of the alveolar walls, hyperplasia of connective tissue 
cells, and phagocytes and macrophages containing absorbed dust particles were observed. The pulmonary micrographs of affected rabbits (K47 and K52) are shown in Fig. 9( $\mathrm{a}$ and $\mathrm{b})$.

Experiment 5: Intratracheal infusion of titanium hydride dust in rats: $\mathrm{TiH}_{2}$ dust under 325 mesh was sterilized by dry heat, dried and suspended in penicillin-supplemented physiological saline solution. As detailed in Table 6, to 39 Wistar strain rats (male, R96-R134, $250.6 \mathrm{~g}$ mean body weight), $1 \mathrm{ml}$ of the dust suspension containing $10 \mathrm{mg}, 50 \mathrm{mg}, 100 \mathrm{mg}$, or $500 \mathrm{mg}$ of dust was infused into the trachea of the rats once by means of an injecting syringe.

After the rats were exposed to the dusts intratracheally, symptoms developing in the animals were observed over the course of a maximum of 486 days, and then the survivals were vivisected for pathological examination.

In these experiments, various changes in bronchioli, lungs and lymph nodes were found histopathologically. As shown in Fig. 10 (a to f), purulent bronchitis, dust cells and giant cells containing foreign material, bronchopneumonia and granulomatous pneumonia, organization of histiocytes in alveoli, intraalveolar fibrosis, macrophages, deposition of titan dust in the alveoli and infiltration of phagocytes, round cells and fibroblasts were shown, and fibrosis were observed, although the fibrosis of tissues was not so pronounced.

\section{Discussion}

The use of such animals as rats, mice, rabbits, dogs and guinea pigs in experimental studies of the pulmonary changes occurring due to titanium dioxide has already been employed by Vernetti, ${ }^{1)}$ Mohr, ${ }^{2)}$ and Strecker. ${ }^{4}$ Though the procedures for exposure to the titanium dioxide adopted by these workers were by intraperitoneal, subcutaneous, intravenous, oral, or aerogenic administration, neither inflammation nor fibrous changes in the lungs were found.

Koelsch $^{5)}$ first described the hazardous pulmonary fibrosis induced by certain hard metals such as tungsten, titanium, tantalum, cobalt, chromium, manganese, and other similar substances.

Schmitz-Moorman et al. ${ }^{7)}$ reported a case of pulmonary changes caused by the inhalation of titanium dioxide dust, and suggested that neither this nor carbon dust produced inflammation or fibrous change in the lung, and that titanium dioxide was biologically inert.

Some systematic studies of pulmonary changes and fibrosis due to titan dust and its pathogenesis were carried out by the present author ${ }^{9,11,12,13,17-23)}$ using rats and rabbits as in the above 5 experiments. The particle size distribution of the titan dust was about $72 \%$ up to $10 \mu \mathrm{m}$, comprising $4-6 \mu \mathrm{m} 26.7 \%$,

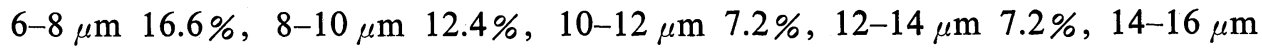
$3.7 \%, 16-18 \mu \mathrm{m} 3.6 \%, 18-20 \mu \mathrm{m} 1.3 \%$ and over $20 \mu \mathrm{m} 4.5 \%$. That of titanium hydride dust particle size was $82 \%$ up to $2 \mu \mathrm{m}$, comprising $1 \mu \mathrm{m}$ 
$37.4 \%, 1-2 \mu \mathrm{m} 44.6 \%, 2-3 \mu \mathrm{m} 8.5 \%, 3-4 \mu \mathrm{m} \mathrm{3.4 \% ,4-6} \mu \mathrm{m} 3.0 \%$ and $6-23$ $\mu \mathrm{m} 3.1 \%$. These titan and titanium hydride dusts were administered by inhalation using an apparatus of $80 \mathrm{~cm}$ diameter, $50 \mathrm{~cm}$ height and 250 litres volume.

As a result of radiographic and histopathological examination, irreversible pulmonary changes caused by the inhalation of titan dust were confirmed. Proliferation of fibroblasts was shown, but the degree of fibrosis was not so remarkable.

Sano, ${ }^{6,8,10,14)}$ and Ishikawa et al. ${ }^{15)}$ suggested no fibrous proliferation was elicited by iron dioxide over a short period, but found, in two autopsy cases, that evident fibrosis occurred as a result of exposure to sufficient amounts of the dust over prolonged periods.

On the other hand, Mitchel ${ }^{16)}$ reported that volcanic ash particles up to $3 \mu \mathrm{m}$ in diameter might accumulate in the lungs, and that generally, particles $5 \mu \mathrm{m}$ or smaller are physiologically significant.

Since 1977 , the author ${ }^{24,25,26,29)}$ has carried out experimental studies on the effects of volcanic ash originating from volcanic eruptions of Mount Sakurajima near Kagoshima City on the respiratory organs of laboratory animals.

The volcanic ash contained a $90.5 \%$ proportion of dust particles under $3 \mu \mathrm{m}$, and the author was able to demonstrate the induction of pneumoconiosis due to dust fibrosis and thus the hazardous nature of volcanic ashe inhalation.

According to the Environmental Health Criteria 24, Titanium, published by the $\mathrm{WHO},{ }^{27)}$ exposure to different titanium compounds appears to induce various levels of slight pulmonary fibrosis. In some experimental studies in which rats and guinea-pigs were exposed to titanium dioxide dust, slight fibrosis was occasionally found in the lung tissue. However, the exposure in these studies was not to pure titanium dioxide and a possible explanation for the fibrogenic activity may be concomitant exposure to other substances, such as silica $\left(\mathrm{SiO}_{2}\right)$. Autopsy studies on workers exposed to titanium dioxide for long periods have not shown any evidence of fibrogenic activity. This is consistent with the few epidemiological surveys made of working populations exposed to titanium dioxide dust. In one report, slight fibrosis was observed, but this may have been due to the coating material containing aluminum silicate rather than the titanium dioxide.

In studies on rats, intratracheal administration of $50 \mathrm{mg}$ of titanium nitride induced a weak fibrogenic effect after 6 months. Slight fibrosis was detected in similar studies in which rats were exposed to titanium hydride, boride, or carbide. Data on the exposure of man to such titanium compounds are lacking.

On the other hand, intratracheal administration of $50 \mathrm{mg}$ of titanium hydride to rats induced dystrophic changes in the myocardium, liver, and kidneys. Similar effects were seen after administration of titanium boride or carbide to rats.

Rüttner et al. ${ }^{28)}$ reported on the pathologic and anatomic changes occurring 
in the lungs of 7 workers who were engaged in the grinding of hard metals such as cobalt, tungsten, niobium, tantalum, molybdenum and titanium and exposed to the dusts for many years. Nodular fibrosis of the type seen in silicosis caused by mixed dusts were shown in 2 cases, diffuse and interstitial fibrosis in another 2 cases, slight reaction with foreign material in a further 2 cases, and granulomatosis with sarcoid-like hyaline degeneration in one case.

Accordingly, it seems that prolonged inhalation of sufficient amounts of titan dust over an extended period of time can produce respiratory disorders and fibrosis in the lungs similar to that caused by iron dioxide.

As a result of these investigations, the inhalation of titan dust or the titan compound $\mathrm{TiH}_{2}$ has been shown to produce respiratory disorders and pulmonary fibrosis in laboratory animals.

\section{ACKNOWLEDGEMEnTS}

The author would like to thanks Mrs. Chisato Yamasaki for her technical assistance in various examinations conducted at the Department of Public Health (Director: Professor Mitsuru Shirakawa), Wakayama Medical College, and to Mr. Shigeru Kawamoto and Mr. Mikio Matsuoka of the Nippon Kinzoku-fun Co., Ltd. in Kyoto City for making up the titanium hydride powder.

Moreover, the author wishes to express his gratitude to Dr. Tadatoshi Miyazaki, pathologist and former Vice President of the Mitsui Institute of Industrial Medicine in Fukuoka Prefecture, for his advice and pathological examinations.

\section{REFERENCES}

1) Vernetti, B. L. (1928). Ricerche cliniche e sperimentali sull'osside di titano, Riforma Med. Napoli, 44, 1516.

2) Mohr, H. J. (1957). Titandioxyd im Gewebe. Beitrag z. Silikoseforschung, Sdb. Grundfragen aus der Silikoseforschung, 2, 581.

3 ) International Labour Office (1959). Meeting of experts on the international classification of radiographs of the pneumoconioses, Occupational Safety and Health, 9 (2), 2.

4) Strecker, F. J. (1960). Chemisch veräderte $\mathrm{SiO}_{2}$-Oberflächen im Tierversuch, Beitr. Silikoseforschung. Grundfragen Silikoseforschung, Bd. 4, 121.

5) Koelsch, F. (1962). Die meldepflichtigen Berufskrankheiten, Vierte, Neuearbeitete Auflage, Urban \& Schwarzenberg, S. 53.

6) Sano, T. (1963). Classification of malignancy grade of pneumoconiosis from clinicopathological view point. The Rep. of The Institute for Science of Labour, No. 62, 1.

7) Schmitz-Moorman, P., H. Hörlein, und F. Hanefeld (1964). Lungenveränderungen bei Titandioxydstaubexposition. Beitr. Silikoseforschung, H. 80, 1.

8) Sano, T. (1965). Pathology of welder's lung and its malignancy. J. of Science of Labor, $41(5), 213$.

9) Shirakawa, M., C. Okuno, et al. (1965), Hygienic investigation in a titan manufacturing factory, Jap. J. Ind. Health, 7 (2), 93.

10) Sano, T. (1966). Welding and pneumoconiosis, J. of Science of Labor, 21 (4), 18.

11) Shirakawa, M., C. Okuno, et al. (1966). Experimental studies on the effects of inhalation 
of titan dusts. (Rep. 1) Short-term exposure to titan dust in rats, Jap. J. Ind. Health, 8 (5), 297.

12) Shirakawa, M., C. Okuno, et al. (1966). Experimental studies on the effects of inhalation of titan dusts, (Rep. 2) Roentgenological observation of the chests of workers in a titan factory, Jap. J. Ind. Health, 8 (3), 187.

13) Shirakawa, M., C. Okuno, et al. (1966). Experimental studies on the effects of inhalation of titan dusts, (Rep. 3) On the effects of titan dusts on rabbits, Jap. J. Ind. Health, 8 (3), 17.

14) Sano, T. (1966). Malignancy grade of dust-developed pneumoconiosis, Rôdô no Kagaku (Science of Labor), 21 (11), 48.

15) Ishikawa, T. and E. Shinokawa (1966). Radiographical findings and respiratory functions in pneumoconiosis caused by amorphous and crystalline carbon dust, J. of Science of Labor, 42 (7), 501.

16) Mitchel, R. I. (1960). Retention of aerosol particles in the respiratory tract, Amer. Rev. Resp. Dis., 82, 627.

17) Shirakawa, M., C. Yamasaki et al. (1967). Experimental studies on the effects of inhalation of titan dusts. (Rep. 4) On the radiological chest findings of rabbits exposed to titan dusts, Jap. J. Publ. Health, 14 (6), 674.

18) Shirakawa, M., C. Yamasaki et al. (1967). Experimental studies on the effects of inhalation of titan dusts. (Rep. 5) Histopathological investigations of various organs of albino rats and rabbits exposed to titanium hydride, Jap. J. Ind. Health, 9 (3), 331.

19) Shirakawa, M. and C. Yamasaki (1968). Experimental studies on the effects of inhalation of titan dusts, (Rep. 6) X-ray findings on the experimental animals exposed to titan dusts, Jap. J. Ind. Health, 10 (4), 226.

20) Shirakawa, M. and C. Yamasaki (1969). Experimental studies on the effects of inhalation of titan dusts. (Rep. 7) Roentgenologic and histopathologic findings in the lungs of animals experimentally exposed to titan dusts, Jap. J. Ind. Health, 11 (3), 83.

21) Shirakawa, M. and C. Yamasaki (1969). Experimental studies on the pneumoconiosis caused by the inhalation of titan dusts, Proceedings of the 16th International Congress on Occupational Health, 182.

22) Shirakawa, M. and C. Yamasaki (1970). Experimental studies on the effects of inhalation of titan dusts. (Rep. 8) On the differences of pulmonary changes following the situation of rats experimentally exposed to titan dusts, Jap. J. Ind. Health, 12 (6), 303.

23) Shirakawa, M. and C. Yamasaki (1972). Experimental studies on the effects of inhalation of titan dusts, (Rep. 9) On the pulmonary findings following the intratracheal infusion of titanium hydride dusts in rats, Jap. J. Ind. Health, 14 (4), 345.

24) Shirakawa, M., R. Fukushima, K. Kyushima, and A. Hirota (1982). An experimental study on pulmonary changes caused by inhalation of volcanic ash from Mount Sakurajima, (Rep. 1) Proceedings of the 55th Annual Meeting on Japan Industrial Health, 352.

25) Shirakawa, M., R. Fukushima, K. Kyushima, and H. Kodama (1982). An experimental study on pulmonary changes caused by inhalation of volcanic ash from Mount Sakurajima, (Rep. 2), Jap. J. Ind. Health, 24 (4), 516.

26) Shirakawa, M., K. Kyushima, H. Kodama, and R. Fukushima (1983). Histopathological investigatilon of the respiratory organs of animals experimentally exposed to volcanic ash from Mount Sakurajima, Proceedings of the 56th Annual Meeting of Japan Industrial Health, 258.

27) WHO (1982). Environmental Health Criteria 24, TITANIUM, Geneve, 11.

28) Rüttner, J. R. und C. F. Furrer (1983). Die Pathologie der sogennanten "Härtmetallstaub-Lunge" und vergleichende Lungenstaub-Analysen, Z. Unfallmed. Berufskr. 75 (4), 191.

29) Shirakawa, M., R. Fukushima and K. Kyushima (1984). Experimental studies on the effects of Mt. Sakurajima volcanic ash on the respiratory organs, Jpn. J. Ind. Health, 26 (2), 130 . 